\title{
Water quality analysis of the PDAM drinking water distribution network at the Baron-Ngobaran management unit, Gunungkidul Regency - Indonesia
}

\author{
Muhammad Ridho Irshabdillah and Margaretha Widyastuti* \\ Department of Environmental Geography, Faculty of Geography, Universitas Gadjah Mada, 55281 Yogyakarta Special Region, \\ Indonesia
}

\begin{abstract}
Baron and Ngobaran Underground Rivers are two sources of water on the southern coast of Gunungkidul Regency, Indonesia. A state-owned water utility company (PDAM) is currently distributing raw water for drinking from these underground rivers to Tanjungsari, Saptosari, Paliyan, Panggang, and Purwosari. In addition to quantity, processing raw water for this purpose needs to consider water quality. Therefore, this study was designed to assess the quality of raw water along the PDAM service lines, starting from a common source through pipelines and, finally, to connected customer property lines, and to analyze its Water Quality Index (WQI). During the field survey, the water quality was measured directly at several points selected by the purposive sampling method and indirectly in the laboratory. These measurements observed physical (temperature and TDS), chemical ( $\mathrm{pH}, \mathrm{NO}_{3}^{-}, \mathrm{Cl}^{-}, \mathrm{CaCO}_{3}, \mathrm{Fe}$ total, $\mathrm{Pb}$ ), and biological properties (total coliform) and compared them with the requirements for drinking water quality published in the Regulation of the Minister of Health No. 492/MENKES/PER/IV/2010. The results showed that except for total coliform, all water quality parameters of Baron and Ngobaran Underground Rivers met the standards. Also, the detected water quality from the sources to customers' taps formed a spatial variation. Based on the WQI analysis results, excessively high total coliform levels on all samples made the raw water biologically unsuitable for direct consumption. Therefore, boiling before use is highly suggested as it can remove coliform bacteria in the water.
\end{abstract}

\section{Introduction}

Gunungkidul Regency, like many other karst landscapes, has a limited number of surface water sources and is frequently exposed to recurrent droughts. Such typicality has led to uneven distribution of clean water. The local government, therefore, appointed a state-owned water utility company, PDAM Tirta Handayani, to regulate and manage drinking water allocation from both quantity and quality standpoints. Currently, this company is responsible for pumping raw water from several subterranean sources, i.e., Bribin, Seropan, Baron, and Ngobaran Underground Rivers, which can release up to $2945 \mathrm{~L} \mathrm{~s}^{-1}$ raw water combined (Bribin $875 \mathrm{~L} \mathrm{~s}^{-1}$, Seropan $950 \mathrm{~L} \mathrm{~s}^{-1}$, Baron $1000 \mathrm{~L} \mathrm{~s}^{-1}$ and Ngobaran $120 \mathrm{~L} \mathrm{~s}^{-1}$ ) [1]. It is serving $50.32 \%$ of the total population of Gunungkidul and $69.51 \%$ of the total population in the service area. The number of connected customer piping has been increasing from year to year, namely from 34890 in 2013 to 47325 property lines in 2018 [1].

Apart from quantity, drinking water supplies also factor in quality. In this case, it refers to the quality of raw water extracted from Baron and Ngobaran Underground Rivers in correlation with public health. Aquifers in karst regions are highly vulnerable to contamination owing to the thin layer of overlying soils, flow concentration in the epikarst zone or carbonate aquifer (a product of intensive fissuring), and direct water recharge system through ponors [2]. These conditions prompt the fast entry of contaminants into the underground river systems that can even reach great distances from the source of pollution. Once pollutant loads are introduced to these systems, they can affect water quality in karst aquifers both spatially and temporally.

Due to these reasons, a comprehensive study of the raw water quality at the Baron-Ngobaran Management Unit of PDAM that is primarily sourced from Baron and Ngobaran Underground Rivers is necessary as it sets the stepping stone to discovering the spatial overview of raw water quality from the sources to the service area. This research set out to (1) determine the raw water quality at the sources (Baron and Ngobaran Underground Rivers), piping systems, and connected customer property lines, and (2) analyze the water quality index. With the resulting spatial overview, any changes in water quality parameters in the service lines will be detectable; thus, it helps to decide which measures can adequately address potential issues like poor water quality.

\footnotetext{
Corresponding author: mwiwik@ugm.ac.id
} 


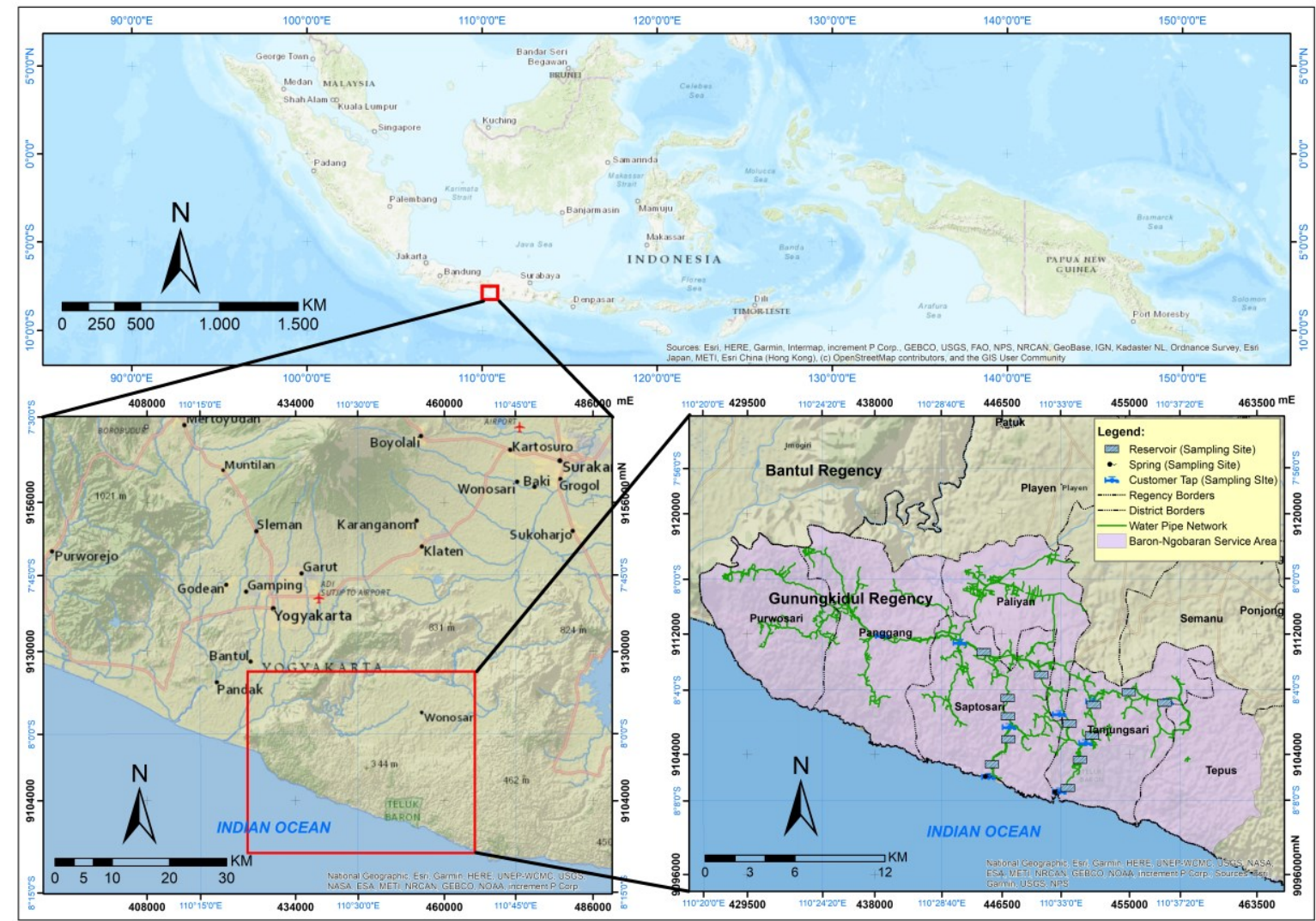

Fig. 1. Water sampling location and the pipeline network of the Baron-Ngobaran Management Unit of PDAM Gunungkidul

\section{Research area}

The Baron-Ngobaran Management Unit of PDAM Tirta Handayani Gunungkidul has several service areas, including Saptosari, Paliyan, Panggang, Purwosari, and parts of Tanjungsari and Tepus Districts (Figure 1). The management unit branch for Baron regulates the extraction of two sources, namely Baron Intake (sourced from Baron Underground River) and Ngobaran Intake (sourced from Ngobaran Underground River). From both sources, only Baron Intake has a Water Treatment Plant (WTP). It has three pumps; each can withdraw water at a discharge of $50 \mathrm{~L} \mathrm{~s}^{-1}$ using a power of 197 KVA (generated by a state-owned electric power supply company, PLN). Meanwhile, Ngobaran Intake has one pump that can withdraw water at a discharge of $60 \mathrm{~L} \mathrm{~s}^{-1}$ using a power of $210 \mathrm{KVA}$.

This management unit also has four transmission lines to the service area. Line 1 distributes water extracted from Ngobaran Intake, which begins at the intake point, extends to Reservoirs R1 to R4, and ends at Reservoir R5. This service line separates into Lines 2 and 3 at Reservoir BR-1, both withdraw water from Baron Intake. While Line 2 starts from Reservoirs BR1, BR-2, BR-3, and ends at Reservoir R5, Line 3 connects Reservoirs BR-1 to BR-5, BR-6, and, finally, BR-7. Line 4 extends from Reservoir R5, where water flows from Baron and Ngobaran Intakes meet and are directly distributed to customers (booster) without passing through another reservoir building.

Distribution lines carry water from the reservoir to customers' taps through a network of galvanized and PVC pipes with diameters ranging between $25 \mathrm{~mm}$ and $100 \mathrm{~mm}$ that connect distribution pipes to transmission pipes and then customer property lines. The water distribution systems of PDAM Tirta Handayani work 20 hours/day with a distribution capacity of $256 \mathrm{~m}^{3} \mathrm{~d}^{-1}$.

\section{Methods}

\subsection{Types of data}

The research drew on primary and secondary data. The primary data were the parameter values of raw water quality from the sources to the service area, and the secondary data included the PDAM pipeline network maps, thematic maps, and other supporting data for analysis. Temperature, TDS, and $\mathrm{pH}$ were the water quality parameters measured directly in the field, while the laboratory tests examined nitrate $\left(\mathrm{NO}_{3}{ }^{-}\right)$, chloride $\left(\mathrm{Cl}^{-}\right)$, hardness $\left(\mathrm{CaCO}_{3}\right)$, heavy metals (iron and lead), and total coliform. For the Baron-Ngobaran Management Unit, the water quality was sampled on March 4-5, 2020 (rainy season) at 24 points: 2 at underground rivers, 13 at reservoirs, and 9 at customer property lines. The drinking water quality standard used 
in the research referred to the Regulation of the Minister of Health No. 492/MENKES/PER/IV/2010 [3].

\subsection{Data analysis technique}

\subsubsection{Spatial analysis of water quality}

A general spatial description of water quality was obtained by analyzing changes in quality from raw water sources to customers' taps. The influencing factors of such variation were analyzed comprehensively by taking into account the conditions of the catchments of Baron and Ngobaran Underground Rivers, sources of pollutants or land use, and the WTP system optimization at Baron Intake.

\subsubsection{Water Quality Index (WQI) calculation}

WQI is an assessment technique illustrating the combined effects of individual water quality parameters on the overall state of water quality [4]. It is crucial in the monitoring of raw water potability. In this research, the WQI used the drinking water quality standard set in the Regulation of the Minister of Health No. 492/MENKES/PER/IV/2010 as a reference [3] and was calculated in four stages $[4,5]$. First, each parameter was given weight value (wi) according to the effect it posed on drinking water quality. Then, the relative weight of the water sample $(\mathrm{Wi})$ was computed using Equation (1):

$$
W_{i}=\frac{W_{i}}{\sum_{i=1}^{n} W_{i}}
$$

where $w_{i}$ is the weight of each parameter and $n$ is the number of parameters.

Second, the quality rating scale (qi) of the water sample was calculated using Equation (2):

$$
q i=\frac{c_{i}}{s_{i}} \times 100
$$

where $C_{i}$ is the concentration of every chemical parameter and $S_{i}$ is the threshold of every chemical parameter, as written in the Regulation of the Minister of Health No. 492/MENKES/PER/IV/2010 [3].

Third, the sub-index value $\left(S I_{i}\right)$ of the water sample was calculated using equation (3):

$$
S I_{i}=W_{i} \times q_{i}
$$

where $W_{i}$ is the relative weight of the parameter and $q_{i}$ is the quality rating scale of the parameter.

Fourth, the water quality index (WQI) was determined based on the equation below (4):

$$
W Q I=>S I_{i-n}
$$

Then, the calculation results were grouped into five classes according to the provisions presented in Table 1 .
Table 1. Classification of drinking water according to

\begin{tabular}{|c|l|}
\multicolumn{2}{c}{ WQI [5] } \\
\hline Range of WQI values & Classes of drinking water \\
\hline$<50$ & Excellent water \\
\hline $50.1-100$ & Good Water \\
\hline $100.1-200$ & Poor water \\
\hline $200.1-300$ & Very poor water \\
\hline$>300.1$ & Unsafe for consumption \\
\hline
\end{tabular}

\section{Results and discussion}

\subsection{Water quality variation in the service lines (sources-reservoirs-customers' taps)}

\subsubsection{Temperature}

The temperature pattern on Line 1 (Ngobaran) showed a declining trend throughout the service line (Figure 2a). Customers' taps had the lowest water temperature because they were located outside the house. Lines 2 and 3 distribute water from the Baron Underground River. Figure $2 \mathrm{~b}$ shows that temperatures were increasingly higher as the water left from Baron Underground River to the reservoirs and reached customers' taps. The same upward trend was also found along Line 3 (Figure 2c).

Line 4 is a distribution line that begins at Reservoir R5, where the transmission lines of Ngobaran and Baron meet. The water in this reservoir is directly distributed to customer piping using a booster system. Based on the distribution pattern, the water temperature tended to decrease as the distance to Reservoir R5 increased (Figure 2d). Such change can be attributed to several factors, including the time of temperature measurement, season, and water storage condition. Measurements in the four service lines revealed a variation in temperature at the raw water sources (underground rivers), the reservoirs, and customers' taps. Nevertheless, this variation was less than significant and still within the specified threshold. Moreover, the time difference in water sample measurement, from noon to late afternoon, is believed to affect the temperature significantly.

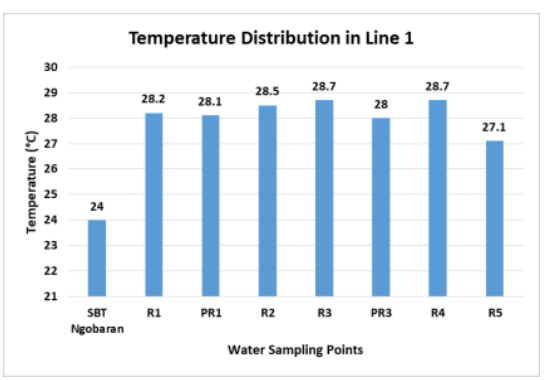

(2a) 


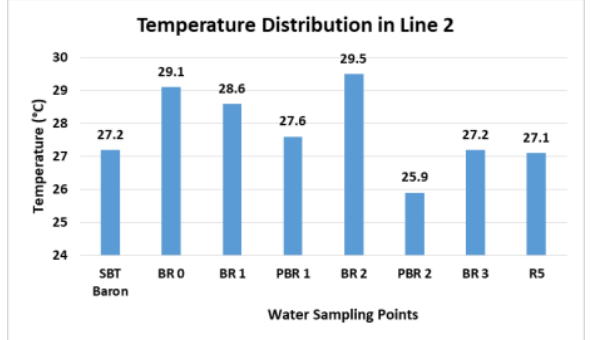

(2b)

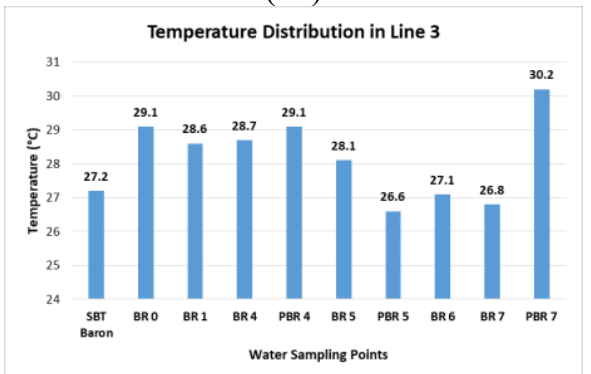

(2c)

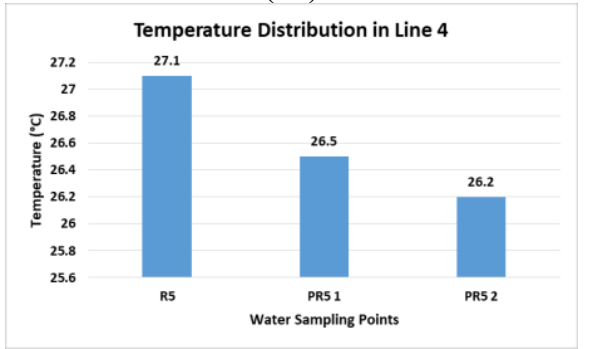

(2d)

Fig. 2. Temperatures of Raw Water Sources (Baron-Ngobaran Underground Rivers), Reservoirs, and Customers' Taps on (a) Line 1, (b) Line 2, (c) Line 3, and (d) Line 4

\subsubsection{Total Dissolved Solids (TDS)}

Line 1 showed that the TDS of water samples collected from costumers' taps did not exceed that of the main reservoirs (Figure 3a). The distribution pattern of TDS levels of customer piping on Line 2 was different from Line 1 (Figure 3b). In the case of Customer PBR-1, the difference might be caused by a one-day pause in the water sampling, where the water sample from this costumer's tap was measured first, while the one from Reservoir BR-1 was measured in the next day. In the home of Customer PBR-2, the water sample was collected from private storage because the tap water was directly channeled to it, meaning that the TDS was more influenced by the condition of the customer's water storage. Water samples of customers' taps on Line 3 showed lower TDS levels than the main reservoir (Figure 3c). The underground river flows were first accommodated in the main reservoirs, allowing the dissolved solids to be deposited at the bottom and, thus, creating a decreasing trend on Lines 1 and 3.

Meanwhile, based on the distribution pattern, the TDS levels on Line 4 increased the distance to Reservoir R5 became longer (Figure 3d) likely because the previously deposited solid substances inside the pipes were dissolved again and then transported by the water flow.

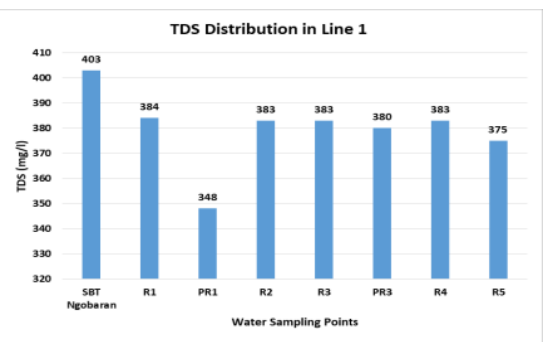

(3a)

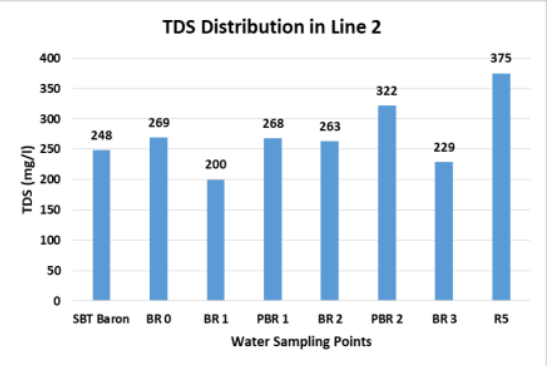

(3b)

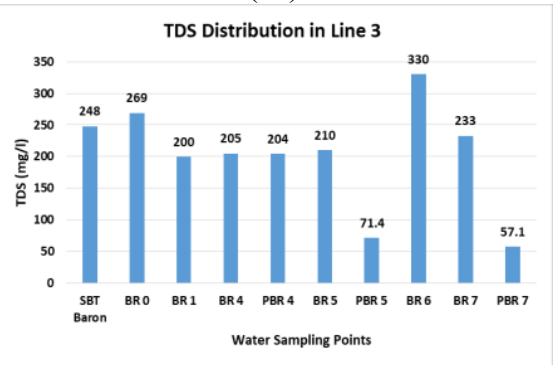

(3c)

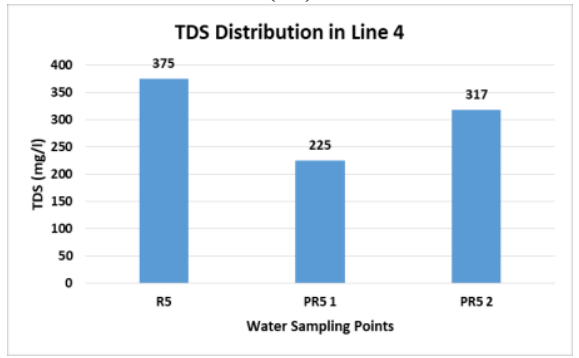

(3d)

Fig. 3. Total Dissolved Solids (TDS) of Raw Water Sources (Baron-Ngobaran Underground Rivers), Reservoirs, and Customers' Taps on (a) Line 1, (b) Line 2, (c) Line 3, and (d) Line 4

\subsubsection{Degree of Acidity ( $p H)$}

On the four service lines, the distribution pattern showed that the farther the distance to the raw water sources/intakes (Baron and Ngobaran Underground Rivers), the higher the $\mathrm{pH}$ value (Figure 4). This pattern is similar to the drinking water quality of PDAM Seropan [6] and PDAM Bribin [7].

$\mathrm{pH}$ values need to be regularly monitored as they may change due to the maintenance of transmission pipelines and drinking water distributions pipes. Water tends to be corrosive at low $\mathrm{pH}$ but induces the formation of crusts inside the pipelines at high $\mathrm{pH}$. 


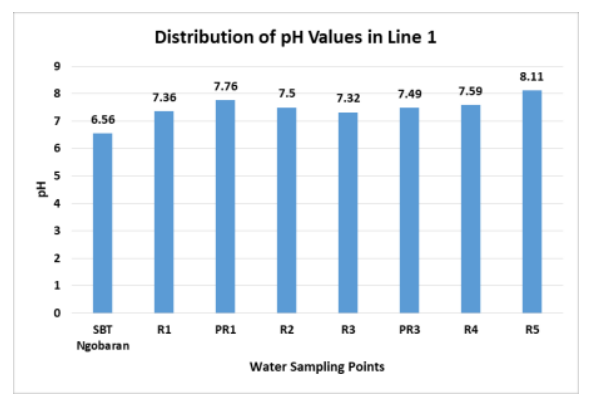

(4a)

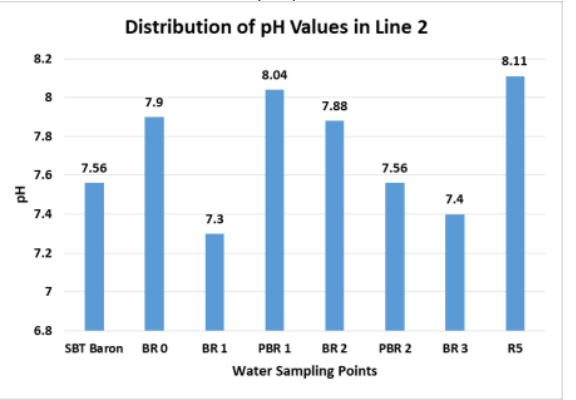

(4b)

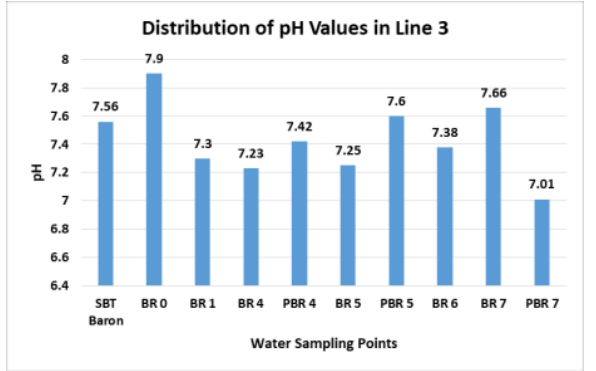

(4c)

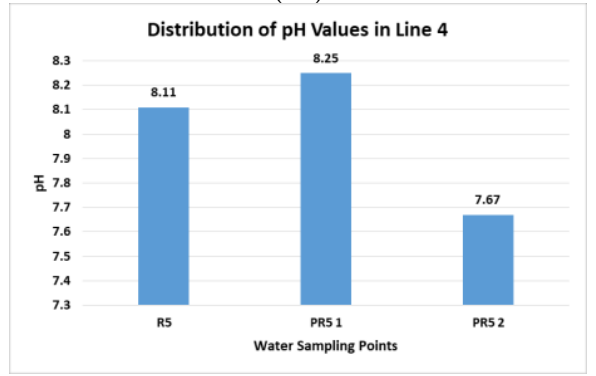

(4d)

Fig. 4. $\mathrm{pH}$ values of Raw Water Sources (Baron-Ngobaran Underground Rivers), Reservoirs, and Customers' Taps on (a) Line 1, (b) Line 2, (c) Line 3, and (d) Line 4

\subsubsection{Nitrate $\left(\mathrm{NO}_{3}^{-}\right)$}

Spatially, the nitrate content of the water samples collected in the service area showed a decreasing trend throughout the service lines (Figure 5). Based on the laboratory test results, the Ngobaran Underground River contained a higher concentration of nitrate than Baron. Consequently, the distribution lines starting from this river (Line 1) generally contained more nitrate than the ones from the Baron Underground River (Lines 2 and 3 ), with a significant difference on Line 2. An increase in nitrate at Reservoir R5 (Line 2) was significant because the water was mixed with the flow of the distribution line originating from the Ngobaran Underground River.

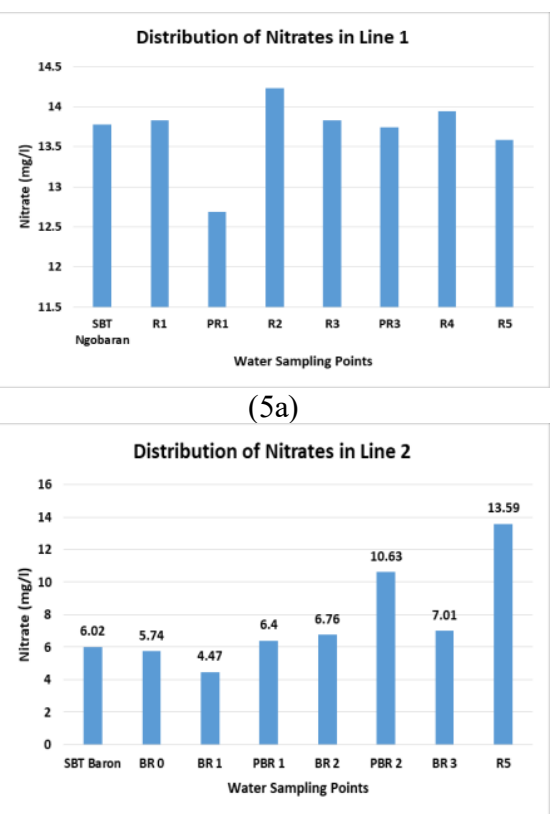

(5b)

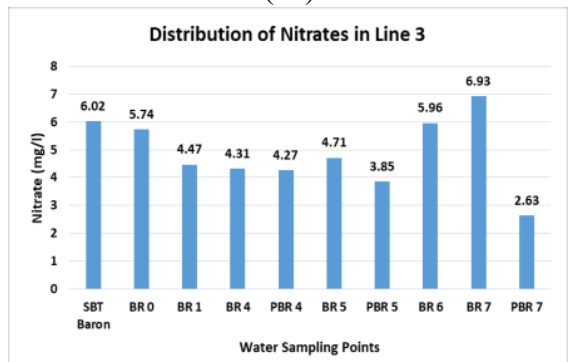

$(5 c)$

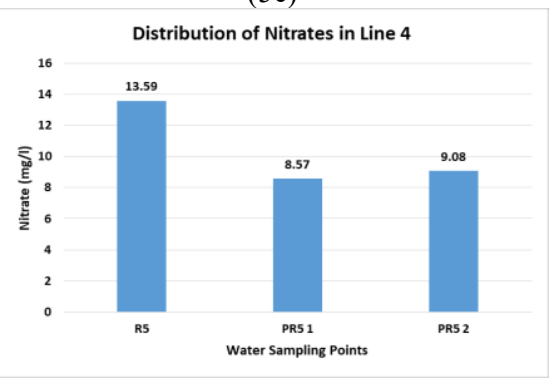

$(5 d)$

Fig. 5. Nitrate Contents of Raw Water Sources (BaronNgobaran Underground Rivers), Reservoirs, and Customers' Taps on (a) Line 1, (b) Line 2, (c) Line 3, and (d) Line 4

\subsubsection{Chloride (Cl)}

As seen in Figure $6 \mathrm{a}$, the distribution pattern of chlorides on Line 1 exhibited a less significant change, or otherwise known as a static trend, from Ngobaran Underground River to customers' taps. It proves that the water reaching the customers on Line 1 does not receive prior treatments. On the contrary, the water distributed from Baron Underground River tended to show increased chloride concentrations, particularly after the water left Reservoir BR-0 (Figures $6 \mathrm{~b}$ and 6c). Meanwhile, along Line 4 (Figure 6d), the water sample collected from Customer PR5-1 (located $5 \mathrm{~km}$ from Reservoir R5) showed a decreasing trend in chloride 
levels, but an increase was detected in the water sample of Customer PR5-2 (10 km from the reservoir).

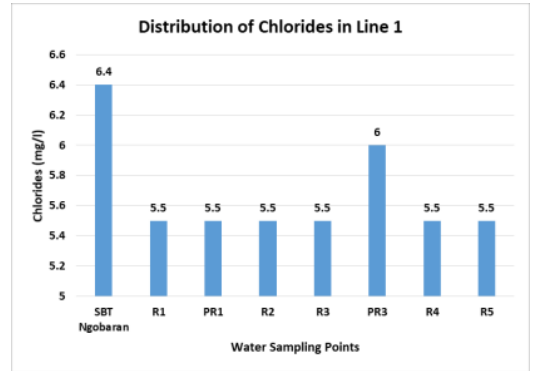

(6a)

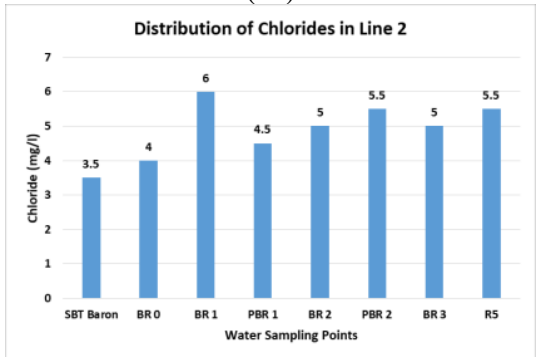

(6b)

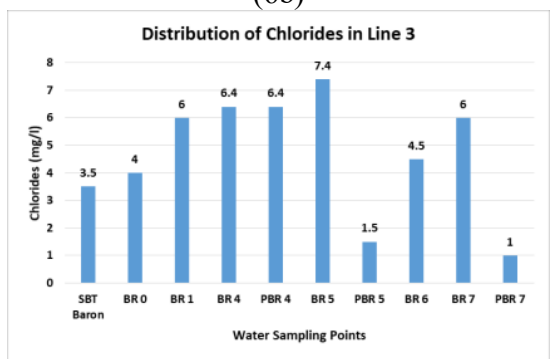

$(6 c)$

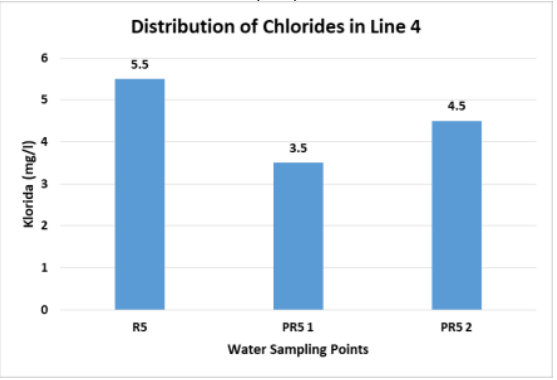

$6 d)$

Fig. 6. Chloride Contents of Raw Water Sources (BaronNgobaran Underground Rivers), Reservoirs, and Customers' Taps on (a) Line 1, (b) Line 2, (c) Line 3, and (d) Line 4

In the WTP, water is treated by adding chlorine powder, and this elevates the chloride concentration $\left(\mathrm{Cl}_{2}\right)$ in the water. Chlorine, in the chlorination process, is reduced to chloride [8]. Therefore, a longer storage time means that more residual chlorine in the water is reduced to chloride. For this reason, customers located farther from Baron Underground River are likely to receive water with a higher chloride content because it has been stored longer in the reservoir. A significant decrease in chlorides in the water samples of several customers' taps was because they were collected from private opened water storage tanks; hence, mixed with rainwater.

\subsubsection{Hardness $\left(\mathrm{CaCO}_{3}\right)$}

Spatially, water hardness on Line 1 showed a downward trend from the underground rivers to customers' taps (Figure 7a). This pattern is categorically unique, considering that this line conveys water from the Ngobaran Underground River that does not have a WTP installation. The distribution lines of water from underground rivers tended to experience irregular increases and decreases (Figures $7 \mathrm{~b}$ and $7 \mathrm{c}$ ). The most substantial increase where the hardness nearly exceeded the upper threshold of the drinking water quality standard was found in Reservoir BR-6, with a hardness level of $470 \mathrm{mg} / \mathrm{l}$. Fluctuation in this parameter was identified on Lines 2 and 3, which also indicates that the WTP installation in Reservoir BR-0 was not functioning optimally.

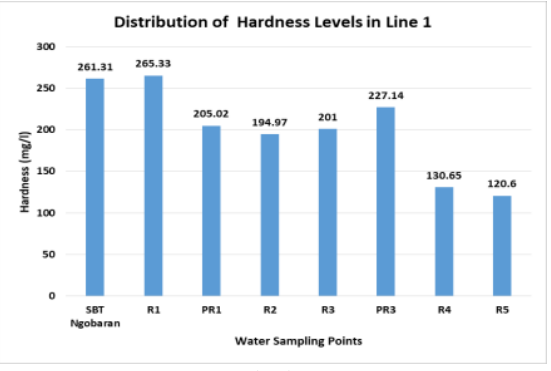

(7a)

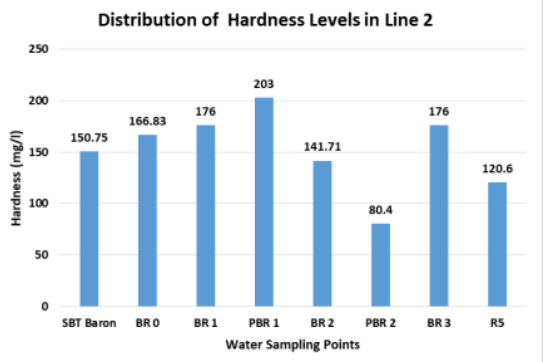

(7b)

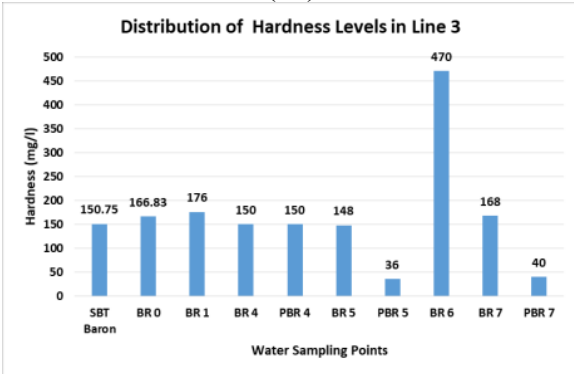

$(7 \mathrm{c})$

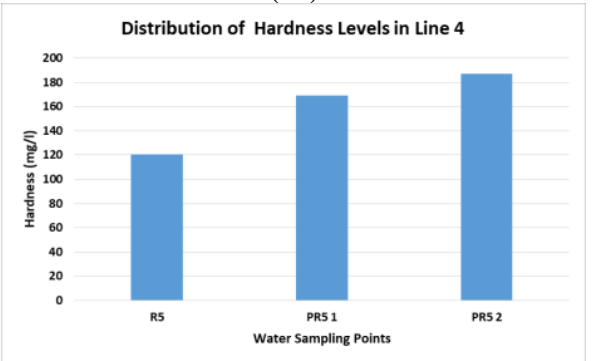

(7d)

Fig. 7. Hardness Levels of Raw Water Sources (BaronNgobaran Underground Rivers), Reservoirs, and Customers' Taps on (a) Line 1, (b) Line 2, (c) Line 3, and (d) Line 4 
Spatially, the $\mathrm{CaCO}_{3}$ concentrations on Line 4 showed a rising trend (Figure $7 \mathrm{~d}$ ). High $\mathrm{CaCO}_{3}$ in the water can also form crusts at the bottom of the customers' cooking utensils.

\subsubsection{Heavy Metals (Fe and $\mathrm{Pb}$ )}

The heavy metals tested in this study were total iron $(\mathrm{Fe})$ and lead $(\mathrm{Pb})$. These two parameters were selected because the pollutants in Bribin-Baron Underground Rivers reportedly include several types of heavy metals [9]. Moreover, pipes that distribute water from the underground rivers are made from iron, while lead is used as a coating agent to inhibit corrosion on these pipes. Laboratory test results showed that the water samples of Baron and Ngobaran Underground Rivers contained iron but no lead. In several water samples collected from the reservoirs and customers, iron and lead contents were found in relatively small concentrations; except for Reservoir BR-6, which contained $0.3652 \mathrm{mg} \mathrm{L}^{-1}$ iron-exceeding the drinking water quality standard. These results indicate that lead concentrations come from water distribution pipes. Therefore, regular monitoring of iron and lead contents along the service lines is highly suggested.

\subsubsection{Total coliform}

The laboratory test revealed that the total coliform-a biological parameter-of all water samples had exceeded the water quality standards written in the Regulation of the Minister of Health No. 492/MENKES/PER/ IV/2010 (Table 1). These results were Too Numerous To Count (TNTC), meaning that the total coliform measured was $>200 \mathrm{CFU} / 100 \mathrm{ml}$. In other words, the presence of coli bacteria in the water samples was far above the ability of the instrument to provide practicable precise enumeration.

For all tested parameters, the analysis results present a different pattern between the Ngobaran Intake distribution line (Line 1), Baron Intake lines (Line 2 and Line 3), and the pipelines starting from Reservoir R5, where water flows from Baron and Ngobaran Intakes meet (Line 4). In general, although the water quality parameters on Line 1 varied in values from the raw water sources to customers' taps, this is not significant from the variations along Lines 2, 3, and 4. The Water Treatment Plant (WTP) facility. which is only available in on the Baron Intake distribution line, is responsible for these findings. Meanwhile, water originating from the Ngobaran Intake is directly distributed without going through the treatment process.

\subsection{Water Quality Index (WQI)}

The water quality index was calculated to determine whether or not the water is suitable or safe for consumption. This measure is of vital importance, given that drinking water can affect the health of the costumers. Based on the WQI analysis, all samples fell into the same range of value or category, that is, unsafe for direct consumption. The WQI of raw water at Ngobaran Underground River was 249.28, significantly lower than the one at Baron Underground River, 2745.22. However, the WQI values of the reservoir water in the Ngobaran and Baron service lines were similar: 2747.14-2750.14 and 2742.36-2765.03, respectively. The same case was true for the WQI values of water samples collected from different customers in these two distribution systems, i.e., 24743.73-2750.80 and 2734.04-2751.36, respectively. When compared to the Regulation of the Minister of Health No. 492/MENKES/PER/IV/2010, only total coliform (biological property) that has exceeded its maximum allowable presence in waters. Meanwhile, temperature, TDS, $\mathrm{pH}, \mathrm{NO}_{3}, \mathrm{Cl}, \mathrm{CaCO}_{3}$, total $\mathrm{Fe}$, and $\mathrm{Pb}$ are still below their respective thresholds. Since the regulation states that water for public consumption must not contain coli bacteria, total coliform is the parameter responsible for such high WQI values. For this reason, boiling prior to use is highly suggested because heating water to its boiling point can inactivate these bacteria [10].

\section{Conclusions}

Direct measurements in the field and laboratory tests have proven that the distribution lines of PDAM Tirta Handayani, organized by the Baron-Ngobaran Management Unit, supply drinking water that meets the quality standards stipulated in the Regulation of the Minister of Health No. 492/MENKES/PER/IV/2010, except for total coliform. Spatially, most of the water quality parameters do not experience a significant change throughout the distribution systems - only specific parameters such as hardness that increases and decreases significantly.

According to the WQI values, all water samples are not safe for direct consumption due to high concentrations of total coliform bacteria. Therefore, before drinking the water, customers are advised to boil it first to kill or inactivate the coli bacteria.

The authors would like to thank Universitas Gadjah Mada for funding this research under the Thesis Recognition Grant scheme (Hibah Rekognisi Tugas Akhir) in the fiscal year of 2020. Gratitude is also extended to PDAM Tirta Handayani in Gunungkidul Regency for their support in research data provision

\section{References}

1. PDAM, Laporan pelayanan air bersih 2019, PDAM Tirta Handayani Gunungkidul, (2019)

2. N. Goldsheider Hydrogeol J. 13,4:555-564 (2005)

3. Government of Indonesia, Peraturan Menteri Kesehatan Republik Indonesia Nomor 492/MENKES/PER/IV/2010 tentang Persyaratan Kualitas Air Minum, (2010) 
4. S. Sadat-Noori, K. Ebrahimi, A. Liaghat, Environ Earth Scis, 71,9:3827-3843 (2013)

5. F. García-Ávila, L. Ramos- Fernández, D. Pauta, D. Quezada, Data in Brief, 18,111-123 (2018)

6. T. Wisnuwati, Evaluasi kualitas air sungai bawah tanah Seropan sebagai sumber air minum Perusahaan Daerah Air Minum (PDAM) sub sistem Seropan Kabupaten Gunungkidul, [Undergraduate thesis], Fakultas Geografi Universitas Gadjah Mada, Yogyakarta, (2013)

7. M. Widyastuti, M.R. Irshabdillah, F. Firizqi, Earth Environ Sci, 451, 012065 (2020)

8. H. Anam, J Med Bio Sains, 1:95-104 (2018) [in Bahasa Indonesia].

9. Sudarmadji, M. Widyastuti E. Haryono, Pengembangan metode konservasi air bawah tanah di kawasan karst system Bribin-Baron Kabupaten Gunungkidul, Laporan Penelitian Hibah Bersaing XIII/1 Universitas Gadjah Mada, (2005) [in Bahasa Indonesia].

10. C.T. Sutrisno, E. Suciati, Teknologi Penyediaan Air Bersih, Rineka Cipta, Jakarta, (2002) [in Bahasa Indonesia]. 